\title{
Modifikasi Deanstark Upaya Efisiensi Proses Distilasi Uap Minyak Biji Pala dalam Praktikum Kimia Organik
}

\author{
Siti Asfiyah", Supaya ${ }^{2}$ \\ ${ }^{1}$ Laboratorium Kimia Organik, Fakultas Matematika Dan IImu Pengetahuan Alam, \\ Universitas Gadjah Mada, Yogyakarta, siti.asfiyah@ugm.ac.id \\ ${ }^{2}$ Laboratorium Kimia Organik, Fakultas Matematika Dan IImu Pengetahuan Alam, \\ Universitas Gadjah Mada, Yogyakarta, supaya@ugm.ac.id
}

Submisi : 26 Agustus 2019; Penerimaan : 11 Februari 2020

\begin{abstract}
ABSTRAK
Telah dilakukan percobaan kombinasi sistem distilasi uap dengan modifikasi deanstark upaya efisiensi proses distilasi minyak biji pala untuk praktikum kimia organik. Destilasi ini bertujuan untuk membandingkan stem distilasi baru modifikasi deanstark dan stem distilasi lama dengan generator uap, meningkatkan hasil distilasi minyak biji pala, mempercepat waktu praktikum, dam mengidentifikasi komponen senyawa dalam minyak biji pala dengan GC-MS.

Percobaan ini diawali dengan isolasi minyak pala menggunakan metode distilasi uap dengan sistem generator sebagai sumber uap air panas yang di dalamnya diisi akuades panas sebanyak $3 \mathrm{~L}$. Isolasi minyak pala menggunakan metode stem distilasi yang dikombinasikan dengan deanstark, digunakan labu 1 L yang diisi akuabides $600 \mathrm{~mL}$ dan dipanaskan selama $1 \mathrm{jam}$. Hasil yang diperoleh dari dua sistem destilasi tersebut kemudian dibandingkan volume minyak atisiri $(\mathrm{mL})$ dan beratnya (g). Minyak atsiri yang didapat selanjutnya diidentifikasi dengan GC-MS.

Hasil percobaan menunjukkan bahwa dengan waktu destilasi uap 1, 2, dan 3 jam dengan sistem generator menghasilkan minyak 0,13,0,24, dan 0,30 $\mathrm{mL}$ dengan berat masing - masing 0,12, 0,10, dan 0,05 g. Sedangkan pada waktu yang sama dengan stem distilasi yang dikombinasikan dengan deanstark diperoleh minyak 0,7, 0,3 , dan 0,1 mL dengan berat masing - masing 0,632, 0,903, dan 0,993 g. Berdasarkan hasil identifikasi dengan GC-MS minyak atsiri biji pala hasil isolasi mengandung komponen sabinene (40,53\%), camphene (21,10\%), dan safrole $(7,13 \%)$.
\end{abstract}

Kata kunci: distilasi uap; deanstark; minyak biji pala; kromatografi lapis tipis.

\section{PENDAHULUAN}

Minyak atsiri atau dikenal juga sebagai minyak eteris (aetheric oil), minyak esensial, minyak aromatik, serta minyak terbang. Salah satu ciri minyak atsiri yaitu bersifat mudah menguap karena titik didihnya rendah. Secara kimia, minyak atsiri tersusun dari campuran yang rumit dari berbagai senyawa. Sebagian besar minyak atsiri termasuk dalam golongan senyawa organik terpena dan terpenoid yang bersifat larut dalam minyak. Sifat minyak atsiri antara lain mudah menguap, rasa yang tajam, wangi yang khas, tidak larut dalam air tetapi larut dalam pelarut organik. Penamaan minyak atsiri disesuaikan dengan sumber utamanya seperti minyak cendana, minyak kayu putih, minyak serai, minyak pala, minyak daun cengkeh, minyak nilam, dll (Agusta,2000).

Pala (Myristica fragans Houtt) merupakan tanaman asli Indonesia, karena tanaman ini berasal dari Banda dan Maluku, yang kemudian menyebar ke pulau-pulau lain sekitarnya, termasuk 
pulau jawa. Tanaman pala terkenal karena biji buahnya yang tergolong sebagai rempah-rempah. Biji dan selaput biji (fuli) atau sering disebut dengan bunga pala, sejak dulu merupakan komoditi ekspor Indonesia dan menduduki $60 \%$ dari jumlah ekspor pala dunia. Bunga pala dalam bentuk kering digunakan sebagai ramuan obat tradisional. Minyak atsiri dan lemak pala terdiri atas $10 \%$ miristin dan monoterpen yang dapat menimbulkan rasa kantuk (Sunanto, 1993), 4\%, pinen, 80\% kamfer, $8 \%$ dipente, safrol $0,6 \%$, egenol, koegenol dan alcohol $6 \%$ (Kartasapoetra,1992).

Salah satu cara memanfaatkan daging buah pala agar tidak menjadi limbah adalah dengan memproduksi minyak atsiri dari jaringan daging buah pala melalui proses distilasi (Ketaren,1995). Menurut Sastroamidjojo (2004), faktor yang mempengaruhi proses distilasi, yaitu kualitas bahan dasar serta faktor teknologi proses.

Minyak pala biasa diperoleh dengan cara destilasi uap dari biji atau fuli pala. Minyaknya tidak berwarna atau kuning dengan odor dan rasa seperti pala, tidak larut dalam air, tetapi larut dalam alkohol dan mempunyai bobot jenis pada $25^{\circ} \mathrm{C}$ antara $0,859-0,924$, refraktif indeks pada $20^{\circ} \mathrm{C}$ antara 1,470 1,488 dan putaran optik pada $20{ }^{\circ} \mathrm{C}$ sekitar $+10^{\circ}-+45^{\circ}$ (Nurdjannah, 2007).

Distilasi uap merupakan suatu metode isolasi zat organik yang tidak larut dalam air dengan mengalirkan uap air dengan prinsip penurunan titik didih campuran. Umumnya distilasi uap digunakan untuk memisahkan campuran senyawa-senyawa yang memiliki titik didih mencapai $200^{\circ} \mathrm{C}$ atau lebih. Distilasi uap dapat menguapkan senyawasenyawa ini dengan suhu mendekati $100^{\circ} \mathrm{C}$ dalam tekanan atmosfer dengan menggunakan uap atau air mendidih (Bahti,1998).
Prinsip dasar distilasi uap adalah mendistilasi campuran senyawa dibawah titik didih dari masing-masing senyawa campurannya. Selain itu distilasi uap dapat digunakan untuk campuran yang tidak larut dalam air disemua temperatur, tetapi dapat didistilasi dengan air. Hal ini dilakukan dengan cara mengalirkan uap air ke dalam campuran sehingga bagian yang dapat menguap berubah menjadi uap pada temperatur yang lebih rendah daripada dengan pemanasan langsung (Jayanuddin, 2011). Aplikasi dari distilasi uap adalah untuk mengekstrak beberapa produk alam seperti minyak eucalyptus dari eucalyptus, minyak sitrus dari jeruk dan untuk ekstraksi minyak parfum dari tumbuhan (Bahti, 1998).

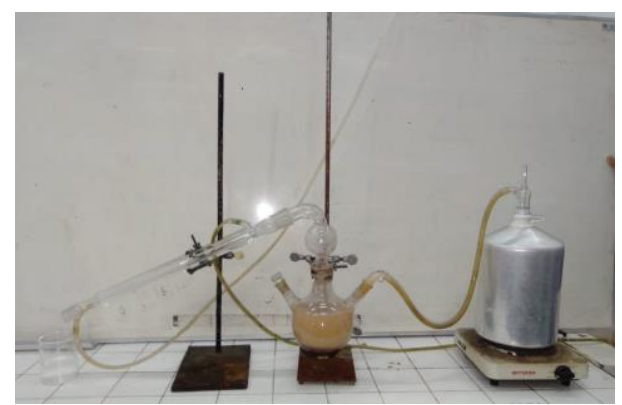

Gambar 1. Rangkaian distilasi uap dengan sistem generator sebagai sumber uap air.

Distilasi uap pada praktikum kimia organik selama ini menggunakan generator uap air seperti pada Gambar 1 akan dipadukan dengan alat modifikasi deanstark yang ditunjukkan pada Gambar 2. Gabungan dari dua alat tersebut diharapkan akan dapat mempercepat waktu praktikum mahasiswa dan hasil destilasi minyak atsiri lebih banyak. Prinsip kerja alat tersebut adalah uap air yang dipanaskan akan membawa uap minyak atsiri dan didinginkan oleh pendingin Liebig masuk ke modifikasi deanstark, minyak atsiri yang berat jenisnya ringan akan ditambung di modifikasi deanstark bagian atas sedangkan airnya akan 
masuk lagi ke labu stem distilasi. Sirkulasi ini berlangsung terus menerus sampai distilasi dianggap selesai.
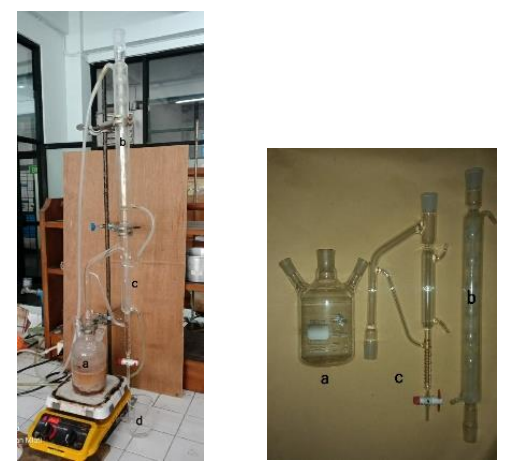

Gambar 2. Rangkaian distilasi uap dengan stem distilasi yang dikombinasikan dengan deanstark (a) labu stem distilasi (b) pendingin bola (c) modifikasi deanstark (d) gelas beaker

Kromatografi lapis tipis merupakan kromatografi serapan yang memiliki fasa diam berupa zat padat dengan fase geraknya berupa zat cair. Prinsip dari pemisahan kromatografi lapis tipis adalah adanya perbedaan sifat fisik dan kimia dari senyawa yaitu kecenderungan dari molekul untuk melarut dalam cairan (kelarutan), kecenderungan molekul untuk menguap dan kecenderungan molekul untuk melekat pada permukaan (Hendayan, 2006). Kromatografi lapis tipis merupakan bentuk kromatografi planar yang digunakan untuk memisahkan senyawa-senyawa yang siatnya hidrofob seperti lipida-lipida dan hidrokarbon (Sastrohamidjojo, 1991). Fasa gerak berupa pelarut atau pengembang yang mengalir melalui penyerap padat. Komponen-komponen dalam campuran (sampel) yang bergerak melalui plat KLT memiliki kecepatan yang berbeda, tergantung pada kelarutan komponen. Karena perbedaan inilah komponen-komponen tersebut dapat terpisahkan satu sama lain. Kromatografi jenis ini dapat dijelaskan untuk dua tujuan yaitu untuk mencapai hasil kualitatif, kuantitatif atau preparatif dan untuk menjajaki sistem pelarut yang akan digunakan dalam kromatografi kolom (Soebagio, 2003). Didalam kromatografi, mobilitas relatif dari komponen sinyatakan dalam satuan retardatcon factor $(\mathrm{Rf})$ yang didefinisikan sebagai berikut:

$$
R f=\frac{\text { Jarak tempuh oleh senyawa }}{\text { Jarak tempuh oleh eluen }}
$$

Kromatografi gas spektrofotometri massa adalah kombinasi dari dua teknik analisis yang sangat baik. Kromatografi gas memisahkan komponen dari campuran dalam waktu tertentu dan spektrofotometri massa menghasilkan informasi yang membantu dalam identifikasi struktur masing-masing komponen serta untuk mengetahui massa molekul relatif (Mr) dari setiap puncak kromatogram (Kitson dkk., 1996). Kromatografi gas-spektrometer massa ini biasa digunakan untuk analisis kualitatif senyawa organik yang pada umumnya bersifat dapat diuapkan. Campuran terdiri dari metil ester minyak nabati yang dapat dianalisis menggunakan gas-spektrometer karena memiliki kriteria tersebut. Pemisahan yang dihasilkan dari setiap jenis senyawa yang dianalisis bersifat khas untuk setiap senyawa (Suryani, 2005).

\section{METODE PENELITIAN}

Bahan yang digunakan untuk membuat rangkaian alat stem distilasi ini adalah generator uap labu leher tiga, pendingin Liebig, deanstark, Erlenmeyer, gelas ukur, gelas beaker, pengaduk kaca, pemanas, lampu UV. Untuk tarap uji cobanya menggunakan bubuk biji pala, etil asetat batu didih, dan akuades. Isolasi Minyak Pala dengan generator uap

Generator uap diisi dengan akuades sebanyak 3L dan dipanaskan. Bubuk biji pala yang telah dihaluskan 
kemudian dimasukkan kedalam labu leher tiga sebanyak $50 \mathrm{~g}$ dan ditambahkan akuades sebanyak $400 \mathrm{~mL}$. Labu leher tiga yang berisi bubuk biji pala kemudian dipasangkan ke alat distilasi dan dipanaskan. Uap dari generator uap dialirkan kedalam sistem distilasi dan distilasi dilakukan selama \pm 1 jam. Setelah itu diperoleh distilat yang terdiri dari dua lapisan. Lapisan minyak tersebut dipisahkan dengan menggunakan corong pisah dan diukur berat serta volumenya.

\section{Isolasi Minyak Pala dengan stem distilasi yang dikombinasi dengan modifikasi deanstark}

Bubuk biji pala yang telah dihaluskan, dimasukkan kedalam labu stem distilasi sebanyak $50 \mathrm{~g}$ dan ditambahkan akuades sebanyak $600 \mathrm{~mL}$. Stem distilasi tersebut dipasangkan ke alat distilasi yang diatasnya sudah di pasang deanstark yang telah dimodifikasi dan selanjutnya dipanaskan. Uap dari stem distilasi uap dialirkan kedalam sistem distilasi melalui deanstark yang sudah dimodifikasi dan distilasi dilakukan selama \pm 1 jam. Distilat yang diperoleh kemudian ditampung di bagian bawah deanstark. Lapisan minyak atsiri tertampung di denstak bagian atas, sedangkan lapisan bawah atau air akan masuk lagi ke labu stem distilasi.Lapisan atas yang tertampung di deanstark diambil dengan cara membuka kran pada deanstark, ditampung dan diukur berat serta volumenya.

\section{HASIL DAN PEMBAHASAN}

Distilasi merupakan proses pemisahan komponen-komponen antara dua atau lebih jenis zat yang memiliki karakteristik berbeda dalam suatu campuran. Minyak atsiri dapat diambil dari beberapa tanaman seperti yang digunakan dalam percobaan ini adalah biji pala. Biji pala mengandung minyak atsiri $10 \%$, dengan komponen yang terdiri dari miristin sekitar $4 \%$, pinen, $80 \%$ kamfer, $8 \%$ dipente, safrol $0,6 \%$, egenol, ko-egenol, alkohol 6\%. Percobaan ini menggunakan bubuk biji pala untuk mempermudah pelarut menjangkau poripori biji pala sehingga minyak atsiri akan lebih cepat keluar dan menghasilkan minyak atsiri lebih banyak. Pelarut yang digunakan adalah akuades, karena akuades memiliki sifat kepolaran yang berbeda dengan minyak atsiri sehingga minyak atsiri akan mudah dipisahkan dari destilat. Akuades dan minyak atsiri tidak saling melarutkan, selain itu titik didih air lebih kecil dari minyak atsiri sehingga uap air akan mendorong minyak biji pala untuk lepas dari pori-pori biji pala.

Prinsip dari destilasi dengan deanstark yaitu pemisahan komponenkomponen suatu campuran yang terdiri atas dua cairan atau lebih berdasarkan perbedaan tekanan uapatau berdasarkan perbedaan titik didih komponen-komponen senyawa tersebut. Pada percobaan ini, campuran uap yang terdiri dari uap air dan uap minyak akan mengalir menuju kondensor untuk dicairkan kembali dengan sistem pendinginan dari luar. Kondensat yang keluar dari kondensor masuk ke deanstark yang memisahkan antara uap air dan uap minyak pala berdasarkan berat jenisnya. Minyak atsiri pala yang berat jenisnya lebih ringan akan ditampung di denstak bagian atas, sedangkan air yang berat jenisnya lebih berat dari pada minyak pala akan keluar dari deanstark masuk ke stem labu destilasi.Proses destilasi dilakukan selama kurang lebih 1 jam. Dari percobaan destilasi uap dengan sistem generator maupun steam distilasi diperoleh hasil minyak pala seperti yang ditunjukkan pada Tabel 1. 
Minyak atsiri yang diperoleh dengan sistem generator tidak berwarna dan memiliki bau khas minyak pala. Berdasarkan hasil percobaan dengan stem distilasi yang dikombinasi dengan modifikasi deanstark diperoleh minyak atsiri berwarna kekuningan, dan lebih efisien dari segi waktu serta hasilnya.

Tabel 1. Hasil distilasii bubuk biji pala dengan sistem generator.

\begin{tabular}{ccc}
\hline $\begin{array}{c}\text { Waktu } \\
\text { (jam) }\end{array}$ & $\begin{array}{c}\text { Volume } \\
\text { Minyak (ml) }\end{array}$ & $\begin{array}{c}\text { Berat Minyak } \\
(\mathrm{g})\end{array}$ \\
\hline 1 & 0,13 & 0,12 \\
2 & 0,37 & 0,22 \\
3 & 0,67 & 0,27 \\
\hline
\end{tabular}

Tabel 2. Hasil distilasi bubuk biji pala dengan stem distilasi

\begin{tabular}{ccc}
$\begin{array}{c}\text { Waktu } \\
\text { (jam) }\end{array}$ & $\begin{array}{c}\text { Volume } \\
\text { Minyak }(\mathrm{mL})\end{array}$ & $\begin{array}{c}\text { Berat Minyak } \\
(\mathrm{g})\end{array}$ \\
\hline 1 & 0,7 & 0,632 \\
2 & 1,0 & 1,535 \\
3 & 1,1 & 2,528 \\
\hline
\end{tabular}

Minyak atsiri biji pala kemudian diidentifikasi menggunakan kromatografi lapis tipis (KLT). Prinsip pemisahan dengan metode KLT didasarkan pada perbedaan polaritas antara sampel dengan eluen. Sesuai asa "like dissolve like", jika eluen yang digunakan nonpolar maka eluen akan memisahkan komponen yang bersifat nonpolar. Etil asetat merupakan larutan yang bersifat semi polar sedangkan $n$-heksana bersifat nonpolar. Secara teoritis, eluen yang baik adalah senyawa yang bersifat nonpolar dan mudah menguap. Eluen bersifat nonpolar karena sampel akan lebih mudah terbawa oleh fasa gerak ketika tingkat kepolarannya sama. Eluen harus mudah menguap karena apabila eluen sukar menguap maka zat tersebut tidak akan dapat dipisahkan karena gaya dorong dari eluen hanya sedikit.Identifikasi minyak atsiri biji pala dilakukan dengan KLT menggunakan eluen etil asetat:n-heksana $(5: 95 \mathrm{v} / \mathrm{v})$ dan diperoleh hasil pemisahan yang ditunjukkan pada Gambar 3.dengan nilai Rf 0,592,0,72,dan 0,85.

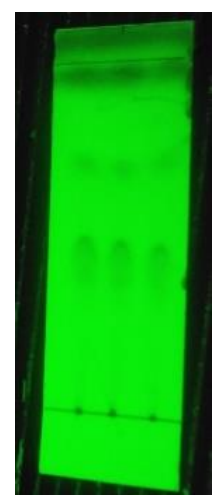

Gambar 3. Profil minyak atsiri biji pala hasil distilasi.

Hasil identifikasi minyak atsiri biji pala menggunakan GC-MS diperoleh 14 puncak, yang berarti ada 14 komponen senyawa pada minyak atsiri bij pala hasil isolasi, seperti ditunjukkan pada Gambar 4.

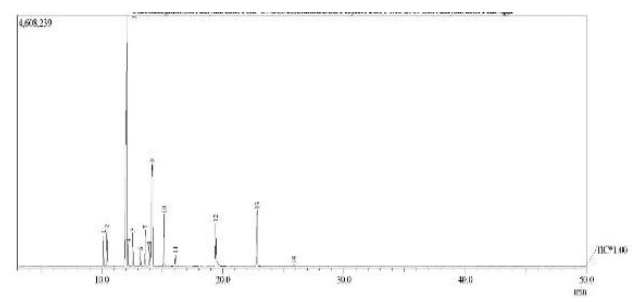

Gambar 4. Kromatografi GC minyak atsiri biji pala.

Identifikasi selanjutnya dilakukan pada tiga senyawa dengan intensitas puncak paling tinggi yang menunjukkan kelimpahan terbanyak dalam minyak atsiri biji pala hasil isolasi yang ditunjukkan pada Tabel 3. Senyawa yang diidentifikasi adalah senyawa dengan nomer puncak 3, 9, dan 13. 
Tabel 3. Data komponen minyak atsiri biji pala

\begin{tabular}{cccccc}
\hline Puncak & $\begin{array}{c}\text { Waktu } \\
\text { retensi } \\
\text { (menit) }\end{array}$ & $\begin{array}{c}\text { \% } \\
\text { Area }\end{array}$ & $\begin{array}{c}\text { Massa } \\
\text { molekul } \\
(\mathrm{g} / \mathrm{mol})\end{array}$ & $\mathrm{m} / \mathrm{z}$ & Senyawa \\
\hline 3 & 12,071 & 40,53 & 136 & $28,41,53,65,77,93,105$, & Sabinene \\
9 & 14,160 & 21,10 & 136 & $27,39,53,67,79,93$, & Camphene \\
13 & 22,836 & 7,13 & 162 & $\begin{array}{c}107,121, \text { dan } 136 \\
27,51,63,77,91,104,\end{array}$ & Safrole \\
\hline
\end{tabular}

\section{KESIMPULAN}

Berdasarkan hasil percobaan dan pembahasan dapat disimpulkan bahwa isolasi minyak pala dengan alat distilasi uap modifikasi deanstark diperoleh hasil yang lebih banyak dibandingkan alat yang lama. Hasil minyak pala yang diperoleh dengan generator uap sebesar 0,67 mL, dan distilasi uap modifikasi deanstark sebesar $1,10 \mathrm{~mL}$ dengan waktu distilasi yang lebih cepat. Hasil analisis dengan metode GC-MS menunjukkan minyak atsiri biji pala mengandung komponen sabinene $(40,53 \%)$, camphene $(21,10 \%)$, dan safrole $(7,13 \%)$.

\section{DAFTAR PUSTAKA}

Agusta, A., 2000, Minyak Atsiri Tumbuhan Tropika, ITB, Bandung.

Bahti., 1998, Teknik Pemisahan Kimia dan Fisika, Universitas Padjajaran, Bandung.

Hendayana, S., 2006, Kimia Pemisahan Metode Kromatografi dan Elektroforesis Modern, PT. Remaja Rosdakarya, Bandung.

Jayanuddin., 2011, Komposisi Kimia Minyak Atsiri Daun Cengkeh Dari Proses Penyulingan Uap, Jurnal Teknik Kimia Indonesia., 10, 37-42.

Ketaren dan Djatmiko, B., 1978. Minyak Atsiri (bersumber dari bunga dan buah). Departemen
Teknologi Hasil Pertanian. FATEMETA, IPB. Bogor.

Nurdjannah N. 2007. Teknologi Pengolahan Pala. Balai Besar Penelitian dan Pengembangan Pascapanen Pertanian, Bogor.

Sastroamidjojo, H., 1991, Kromatografi, Universitas Gadjah Mada Press, Yogyakarta.

Sastroamidjojo, H., 2004, Kimia Minyak Atsiri, Universitas Gadjah Mada Press, Yogyakarta.

Sunanto, H., 1993, Budidaya Pala Komoditas Ekspor, Penerbit Kanisius, Yogyakarta 